contains several artificial ponds and it is traversed by $12 \mathrm{~km}$. of roads. As described by F. N. Rusanov (Priroda, 7, 61; 1959) the dendro park contzins many well-acclimatized, rare and valuable plants and hybrids. The park is at the sorvice of the whole of Central Asia.

\section{Submarine Oil Drilling}

According to M. K. Kalinko (Priroda, 11, 25 ; 1959), the first attempt to extract petroleum from rocks underlying the bottom of the Caspian Sea were made in the region near Baku in the beginning of the nineteenth century. The workings, protected by two wooden frames lowered at the bottom of the sea, were destroyed by a storm in 1825. In 1910, in an attempt to infill a shallow bay, petroleum was discovgied, which led to drilling in the region; but planned survey and undersea petroleum extraction began only in 1935. At the present time, undersea extraction is carried out on a large scale in eight separate areas in the region of Baku, and in 1958 this work extended to the eastern part of the Caspian Sea. Outside Russia, the submarine extraction of petroleum began in Japan in 1888, but it reached its maximum development in the Gulf of Mexico, California, Venezuela, and the Persian Gulf. Special surveying and prospecting methods are now employed for the investigation of the possible offshore petroleum provinces or 'aquatories'. 'The author of this article gives a general survey of the world's offshore petroliferous provinces, which in his opinion may yield more petroleum than the overland provinces.

\section{Use of Gamma-Radiation Sources for the Steriliza- tion of Pharmaceutical Products}

A report issued by the Association of the British Pharmaceutical Industry (B.M.A. House, Tavistock Square, London, W.C.1. Pp. 17) describes the findings of a working party set up by a number of pharmaceutical firms and other interested bodies, including the Atomic Energy Research Establishment, to investigate whether pharmaceutical products and containers could be usefully sterilized on a commercial scale by using gamma-radiation. The results of the tests are summarized in a convenient form in this report. A dose of $2.5 \times 10^{3} \mathrm{rads}$ (from cobalt-60) appeared to be adequate to achieve sterility, but it caused changes in many of the substances tested, and in many cases rendered them unsuitable for use. It is suggested that the method may be usefully applied in particular cases, but the results, in general, are not considered sufficiently encouraging to justify continuation of the present investigation on a group basis.

\section{Molecular and Crystal Structure Models}

A BIBLIOGRAPHY on molecular and crystal structure models used extensively in research and as teaching aids has recently been published (U.S. Department of Commerce: National Bureau of Standards. Monograph No. 14: Bibliography on Molecular and Crystal Structure Models. By Deane K. Smith. Pp. iv +7 . Washington, D.C.: Government Printing Office, 1960 . 15 cents). The references are grouped into four broad classifications-models in general, static models, dynamic models, and constructional devices-and the static model classification is, in addition, subdivided into closed molecular (Stuart type), closed packing, open molecular, open crystal structure, open with parallel rods, polyhedral, and miscellaneous models. The list of references is preceded by brief explanations of the various types of model which indicate the more significant articles relating to them.

\section{Hæmatology of the Central Australian Aborigine}

VARIous hæmatological observations on central Australian aborigines have been made by J. R. Casey-Smith, of the Department of Anatomy, University of Adelaide (Austral.J. Exp. Biol. and Med. $S c i$.). One group contained some thirty nomadic males living under primitive conditions for most of the year. The second group consisted of about twenty males and fifteen females living under urban conditions, on an almost European diet. The nomadic group's diet had a high iron content. The hæmoglobin-levels of a control group of Europeans in Central Australia were also measured. Hæmoglobin and hæmatocrit values of the nomads were higher than those of the 'urban' males ; neither sex of the 'urban' community differed significantly from the European controls. The erythrocyte counts showed no significant difference between the two male groups. Hæmoglobin-levels of sixteen Europeans living at Alice Springs were almost the same as those of the 'urban' males. The mean corpuscular volumes and the mean corpuscular hæmoglobins of the nomads were just. greater than those of the Europeans, but the 'urban' natives did not differ significantly from either the nomads or Europeans. The mean corpuscular hæmoglobin concentrations did not differ significantly between the groups or from European standards. Erythrocyte osmotic fragilities showed an increase in hæmolysis at $0.5 \mathrm{~N}$, but otherwise were not significantly different from those of Europeans. The aborigines did not differ significantly among themselves. The erythrocyte sedimentation-rates were greater in all groups of aborigines when compared with Europeans, but the nomads' values were less than those of the urban groups.

\section{Virus-Streak Disease of Tomatoes}

THE syndrome of the streak disease of tomatoes in Ontario has been shown to be double-virus in nature, resulting from the synergistic action of tobacco mosaic virus and potato virus $X$ (MacNeill, B. H., and Ismen, Hikmet, Canad. J. Bot., 38, 9; 1960). Expression of the disease was found to depend on both virus components of the complex, a variation in strain characteristics of either tobacco mosaic virus or potato virus $X$ being reflected in the intensity of their interaction in the tomato. The extreme severity of streak in the greenhouse and field tomato crops in Ontario is associated with what appears to be a geographical strain of tobacco mosaic virus. This virus is characterized by the induction of primary local lesion in petunia without subsequent systemic invasion of that host. Air temperature profoundly affects the development of streak, symptoms being masked above the critical temperature of $26^{\circ} \mathrm{C}$. This phenomenon is a true masking effect with both viruses becoming latent in the tomato host.

\section{Excavation of La Grotte de Rocherei]}

$\mathrm{IT}_{\mathrm{T}}$ is a pleasure to direct attention to a straightforward cave excavation where the finds are of prime importance and are not dependent on a statistical or other theory which has to be demonstrated ("La Grotte de Rochereil", by P. E. Jude, Mém. 30, Arch. Inst. Paléont. Humaine. Masson et Cie., Paris). 